\title{
MODELLING OF THE POSSIBLE INTEGRATION CONSEQUENCES OF THE ECONOMY OF UKRAINE INTO THE ECONOMIES OF THE EUROPEAN UNION OR RUSSIA
}

\author{
Lesya BUYAK', \\ Ternopil National Economic University, Ukraine \\ Mariya HRYHORKIV', \\ Yuriy Fedkovych Chernivtsi National University, Ukraine
}

\begin{abstract}
The purpose of the paper is to mathematically reproduce the process of economic partnership between the two countries and its qualitative analysis, which include the following goals: to identify feasible outcomes, to formulate requirements for the selection of control parameters and coefficients, to give economic reasoning of the results of modelling and to provide alternative scenario of economic cooperation. Methodology. A method of mathematical modelling has been applied to investigate the possible socio-economic impact of integration of Ukraine into the EU economy. We are describing the basic mathematical model of the economy of Ukraine and two mathematical models of the possible convergence with the economies of the European Union or Russia. The results of modelling are reflected by the capacity of relevant dynamic systems and the quantitative distribution of savings. Results. On the basis of economic analysis of mathematical dependence, the conclusions on the possible economic consequences of integration of Ukraine into the economy of the European Union or Russia have been established. Practical implications. It has been found that a step towards the European Union (EU) requires the alteration of principles of economic management, timely government control. This should be done in the process of restructuring of social standards and commercial activity in terms of traditional forms of management of enterprises with low financial capacities. The process of convergence with the economy of Russia leads to conservation of the modern type of economy with many disadvantages of commercial management and government control as well as limitation of economic and political freedoms and growth of political instability in the country. Value/originality. The got results extend modern economic and mathematical tool for research of integration processes and acceptance of the proper economic decisions. Formalization of models of economy taking into account influence of the economic structured society on economic development allows at model level to probe difficult dynamic processes and possible consequences of integration of economy of Ukraine in the economy of European Union or Russia.
\end{abstract}

Key words: economic partnership, economic modelling, mathematical model, economic dynamics, economic structure of a society.

JEL Classification: F02, F42, C32, E25

\section{Introduction}

Since the establishment of independence Ukraine is deeply integrated into the global economy, however remains one of the few major countries in Europe that have not been included in integration associations. The strategic objective of Ukrainian foreign policy is its active involvement in the European integration process. Relations between the EU and Ukraine are characterized by a wide range of links. They provide trade and investment, regional cooperation and technical assistance.
A characteristic feature of the modern global development of the countries is stirring up of the development of integration processes in the whole world and Europe in particular. However, even those countries that are not part of the integration associations inevitably feel the impact of the processes. They are themselves very complex, so it is necessary to understand what we need for effective entry into the EU area and what problems may Ukraine face on its way. Regarding macroeconomic stability when joining the EU, Ukraine should boost its

\footnotetext{
Corresponding author:

${ }^{1}$ Department of Economic Cybernetics and Informatics, Ternopil National Economic University.

E-mail: lesyabuyak@ukr.net

${ }^{2}$ Department of Economic Modeling and Business Informatics, Yuriy Fedkovych Chernivtsi National University.

E-mail: gmvmarichka@gmail.com
} 
economic performance up to European standards, create a fairly developed market, consolidate the trend towards economic growth. Ukraine will also benefit from the introduction of the single currency when entering the EU. As to additional investments in the economy of Ukraine, the European market is a large market for products sale and source for meeting the needs.

However, structural defects of foreign trade cooperation have become apparent. They lead to the rapid growth of negative trade balance. Economic disadvantages stipulate loss of competitiveness of certain sectors, the complexity of transition to European level of prices, allocation of quotas of certain products. The transfer of potentially hazardous industries to Ukraine, purely raw-exports role of our country, low-paid manpower, growth of demographic cut and illegal migration, all of them are threatening to Ukraine.

Ukraine is interested in strengthening of economic cooperation with the Customs Union countries, since a basis of interest in cooperation with members of the Customs Union is a strategic economic interests of Ukraine. That is the creation of a favourable and predictable business environment in their mutual relations; promotion for the restructuring and modernization of the national economy, with a significant increase of mutual turnover of high-technology products and services; coordination in the markets of third countries; increasing the share of the real sector of economy and strategic industries through industrial and technological cooperation among the enterprises of Ukraine and Russia in the fields of high technology sector, energy sector, mechanical engineering, space, electronics, shipbuilding and aerospace, energy, transport and agricultural engineering, chemical, light and food industries, agriculture and others. The structure of foreign trade of Ukraine displays its simultaneous orientation towards both integration associations.

Therefore, the objectives of creating the conditions for sustainable economic development requires adequate foreign economic strategy that would give answers to issues related to the development of appropriate positioning of the state in the international division of labour. In particular, the issue of benefits and risks Ukraine might face by implementing alternative scenarios of co-operation with the Customs Union is becoming of utmost importance.

The concerns of bilateral relations between Ukraine and Russia are reflected in numerous works of local scientists V.S. Budkin, V.M. Heyets, L.I. Fedulova, V.K. Khaustova, L.V. Shynkaruk. For example, a recent scientific report of experts from the Institute of Economics and Forecasting NASU (National Academy of Sciences of Ukraine) has results of studies on the possible effects of trade conflicts between Ukraine and Russia, and ways of cooperation with the Russian side in various sectors of engineering. At the same time, an attempt to predict the Ukrainian-Russian cooperation, considering modern realities of international economic relations in the post-Soviet areas, was made by Russian scientists, such as O.A. Bazaluk, N.N. Bondariova,
N.I. Komkov, V.V. Kotilko and others. Full description of research results follow in (Buyak \& Pauchok, (2012). Some of the features of modern Ukrainian economic relations are covered in the conceptual framework of this research in (Buyak \& Pauchok, (2013). Certain issues of potential economic interaction of Ukraine with EU countries have been taken as the research material from works in (Buyak, (2013). In has beed emphasized that introduction of commercial practices and social standards of the European Union (Toshkov, (2011) in our country, will lead to rapid transition of socio-economic processes (which require appropriate regulation) and the convergence of low-production economy of our country with highly productive economies in the EU without giving up modern principles of economic management in Ukraine. It will also stipulate simplification of the economic structure of society in Ukraine. Modelling the quantitative characteristics of the possible integration of Ukraine into the Customs Union (CU) was carried out regarding the existence and dynamics of the analysis of $\mathrm{CU}$ before and after its foundation. The analysis of the results of quantitative assessments of changes in terms of trade and their impact on individual members of the integration bloc has also been factored in. The experience of forecasting the results of Ukraine's accession to the WTO and the actual performance of export-import activities over the next three years have been analysed. However, these studies have not examined the possible effects of alternative convergence of Ukraine's economy with the economies of the European Union or Russia.

These processes can be possibly predicted in the light of synergy. First of all, it is necessary to analyse the existing system, develop a list of factors that negatively impact its self-organization and determine the critical moment of bifurcation. Today social model of Ukraine has no balance, along with this, full of aspirations for drastic changes towards existing European standards. The European social model is a balance between economic prosperity and social justice. It provides full employment, quality jobs, equality of chances, social protection. This is one of the facets that distinguishes Europe, where social progress in the postwar years, followed closely by the economic growth from the American model, where a small group of individuals gained an advantage due to the greater number of people (Malkov, Malinetskiy \& Kurdyumov, (2002). The level of welfare of Ukrainians is considerably lower than the European standards. Its increase is solely possible after fair redistribution of income which is received from the business between owners and employees, overcoming of tax minimization schemes and shadow economy. The solution is to develop new scientific projects, IT technologies, further upgrading of all levels of society and production (Toshkov, (2011).

The objective of the article is to mathematically reproduce the process of economic partnership between the two countries and its qualitative analysis, which include the following goals: to identify feasible outcomes, 
formulate requirements for the selection of control parameters and coefficients, to give economic reasoning of the results of modelling and provide alternative scenario of economic cooperation.

\section{Conceptual fundamentals of the modelling}

Let us consider the conceptual framework of model of economy of Ukraine and take two groups of participants workers (their number is $n_{1}$ ) and business owners (their number is $n_{2}$ ). Their amount of savings corresponds to $u_{1}, u_{2}$. Part $\alpha_{1}(i=1,2)$ of savings they spend on private consumption, part $\beta_{1}(i=1,2)$ - for industrial consumption $\left(\alpha_{1}=1 F\left(\beta_{2} u_{2} / p\right) ; \beta_{1}=0 ; \alpha_{2}+\beta_{2}=1\right)$. Business owners produce one type of aggregate product for the price $p$.

Amount of product belonging to business owner is described by the production function $F\left(\beta_{2} u_{2} / p\right)$, depending on capital provision $\beta_{2} u_{2} / p$. Amount of consumed product is described by the function of consumption $Q\left(\alpha_{i} u_{i} / p\right)$ depending on the purchasing power $\alpha_{i} u_{i} / p(\mathrm{i}=1,2)$. This function is piecewise convex. It has a curve in the area between purchasing power at the level of consumption of daily goods and durable goods (Chernavskiy, Starkov \& Shcherbakov, (2002).

Workers earn salary $s_{1}$ and pay income tax $\kappa_{1}$. Business owners pay tax on payroll budget $\chi_{2}$ and income tax $\kappa_{2}$ and incur production expenses $\lambda_{2}$.

Let us work out an equation of the model of economy of Ukraine (without external influences). The rate of savings change $u_{1}$ of workers is proportional to difference between their income (salary $s_{1}$ ), minus tax $\kappa_{1}$ and spending for personal consumption:

$$
\frac{d u_{1}}{d t}=s_{1}\left(1-\kappa_{1}\right)-p Q\left(\alpha_{1} u_{1} / p\right)+\xi_{1}(t),
$$

where $\xi_{1}(t)$ is a random function with zero expectation that simulates random revenues and expenditures of workers.

The rate of savings of business owners is proportional to difference between their profit on sales and expenditures on salary for workers and on production needs as well as personal consumption:

$$
\begin{aligned}
& \frac{d u_{2}}{d t}=\frac{1}{n_{2}} \sum_{i=1}^{2} n_{i} p Q\left(\alpha_{i} u_{i} / p\right)-p Q\left(\alpha_{2} u_{2} / p\right)- \\
& -\frac{n_{1}}{n_{2}}\left(1+\chi_{2}\right) s_{1}-\left(\lambda_{2}+\kappa_{2}\right) p F\left(\beta_{2} u_{2} / p\right)+\xi_{2}(t),
\end{aligned}
$$

where $\xi_{2}(t)$,-is a random function with zero expectation that simulates random revenues and expenditures of owners.

The rate of price change $p$ of goods depends on the difference between the actual consumption by workers $Q\left(\alpha_{1} u_{1} / p\right)$ and a part of «market basket» $\mathrm{Q}_{\theta}$ which is subjectively planned by monopoly market:

$$
\frac{d p}{d t}=\theta\left[Q\left(\alpha_{1} u_{1} / p\right)-Q_{0}\right]+\xi_{p}(t),
$$

where $\theta$ is inertia parameter, $\xi_{p}(t)$ is a random function with zero expectation that simulates random deviations price. Equation (3) corresponds to a closed economy in which most citizens can not achieve consumption level higher than daily living needs.

The solutions of equations (1) and (2) are random values that are describing the statistical distributions $R_{1}(u), R_{2}(u)$, indicating the number of participants in the economy that have savings $[u, u+d u]$. Since equation (1), (2) are of Langevin type, in the stationary case their solutions are describing well known distributions (Tikhonov, (1982)):

$$
\begin{aligned}
& R_{1}\left(u_{1}\right)=R_{10} \exp \left(-2 V_{1}\left(u_{1}\right) / G_{1}^{2}\right), \\
& R_{2}\left(u_{2}\right)=R_{20} \exp \left(-2 V_{2}\left(u_{2}\right) / G_{2}^{2}\right),
\end{aligned}
$$

where $R_{10}, R_{20}$ are normalization coefficients and $G_{1}$, $G_{2}$ are the parameters dependent on functions $\xi_{1}, \xi_{2}$. Parameters $V_{1}, V_{2}$ are describing the effective demand:

$$
\begin{aligned}
& V_{1}\left(u_{1}\right)=\int_{0}^{u_{1}^{1}}\left[s_{1}\left(1-\kappa_{1}\right)-p Q\left(\alpha_{1} u_{1} / p\right)\right] d u_{1}, \\
& V_{2}\left(u_{1}, u_{2}\right)=\int_{0}^{u_{2}}\left[n_{1} n_{2}^{-1}\left(p Q\left(\alpha_{1} u_{1} / p\right)-\left(1+\chi_{2}\right) s_{1}\right)-\left(\lambda_{2}+\kappa_{2}\right) p F\left(\beta_{2} u_{2} / p\right)\right] d u_{2} .
\end{aligned}
$$

Since, $\xi_{1}, \xi_{2}$ functions are statistically independent, the potential of the dynamic system (1), (2) eaquals the sum of potentials

$$
\tilde{V}\left(u_{1}, u_{2}\right)=V_{1}\left(u_{1}\right)+V_{2}\left(u_{1}, u_{2}\right) \text {. }
$$

Potential $\tilde{V}\left(u_{1}, u_{2}\right)$ is describing a surface in the range of values $u_{1}, u_{2}$. Let us select the savings of workers $u_{1}=u_{1}^{*}=$ const which are close to their actual value. Omit the suffix number in the savings of business owners. The function

$$
V(u)=\tilde{V}\left(u_{1}^{*}, u\right) \text {. }
$$

is describing potential of business owners for the value $u_{1}=$ const of the workers' savings and determines the effective demand of producers as well as consumers at the same time. The appropriate distribution of business owners' savings $\left(G_{2}\right.$ is replaced with $\left.G\right)$ :

$$
R(u)=R_{20} \exp \left(-2 V(u) / G^{2}\right) \text {. }
$$

The graphics of functions $V(u), R(u)$ are shown in Figure 1.

\section{Mathematic model of economic convergence with the economy of European Union}

Let us consider how the model will change (1)-(3) if implementation of reforms, which meet legal standards and practice of economic management in the EU, comes possible. Some features of the implementation of this practice were provided by draft treaty of EU (Hnativ, Kostrobiy \& Tokarchuk, (2011)).

After the possible entry of Ukraine into the EU, business owners receive income from exports of goods to the EU at price in the amounts of $\bar{Q}(t)$ :

$$
\begin{aligned}
& \frac{d u_{2}}{d t}=\frac{1}{n_{2}} \sum_{i=1}^{2} n_{1} p Q\left(\alpha_{i} u_{i} / p\right)+\bar{p} \bar{Q}(t)(1-\mu)-p Q\left(\alpha_{2} u_{2} / p\right)- \\
& -\frac{n_{1}}{n_{2}}\left(1+\chi_{2}\right) s_{1}-\left(\lambda_{2}+\kappa_{2}\right) p F\left(\beta_{2} u_{2} / p\right)+\bar{\xi}_{2}(t),
\end{aligned}
$$

where $\mu$ is customs tariff, $\bar{\xi}_{2}(t)$ is a random function that simulates deflection of entrepreneurs' savings. 
Under the terms of compliance with the European practice of economic management, pricing will depend not on the subjective planning (3), but on the difference between the demand for the product and its supply

$$
\frac{d p}{d t}=\theta\left[\sum_{i=1}^{2} n_{i} Q\left(\alpha_{i} u_{i} / p\right)-n_{2} F\left(\beta_{2} u_{2} / p\right)\right] \text {. }
$$

Dynamic system (2e) is described by a potential of:

$$
\begin{aligned}
& V_{e 2}\left(u_{1}, u_{2}\right)=\int_{0}^{u_{2}}\left[n_{2}^{-1} n_{1}\left(p Q\left(\alpha_{1} u_{1} / p\right)-\left(1+\chi_{2}\right) s_{1}\right)+\bar{p} \bar{Q}(t)(1-\mu)-\right. \\
& \left.-\left(\lambda_{2}+\kappa_{2}\right) p F\left(\beta_{2} u_{2} / p\right)\right] d u_{2} .
\end{aligned}
$$

If we take $\tilde{V}_{e}\left(u_{1}, u_{2}\right)=V_{1}\left(u_{1}\right)+V_{e 2}\left(u_{1}, u_{2}\right)$ into account, with $u_{1}=u_{1}^{*}=$ const we will get

$$
V_{e}(u)=\tilde{V}_{e}\left(u_{1}^{*}, u\right) \text {. }
$$

Appropriate distribution of business owners' savings:

$$
R_{e}(u)=R_{20} \exp \left(-2 V_{e}(u) / G^{2}\right) \text {. }
$$

The graphics of functions $V_{e}(u), R_{e}(u)$ (formula (4e), (5e) and (4), (5) similar) are shown in Figure 1. Equation (1), (2e), (3e) and functions $V_{e}(u), R_{e}(u)$ are describing the possible impact of the European practice of management on the economy of Ukraine.

Let us consider the economic conclusions arising from the mathematical properties of functions $V(u), R(u)$, $V_{e}(u), R_{e}(u)$. The properties of these functions regarding the economy of Ukraine have been deeply studied. The potential of our economy has two minima that meet steady states of low-production and high-performance are described in Fig. 1 (They are indicated as $U_{1}, U_{2}$ ). At points of the minimum $V(u)$ distribution $R(u)$ has got maxima which are describing the main economic groups of the participants of economy. The majority of producers in Ukraine have low financial capacity that corresponds to the maximum $R(u)$ at the $U_{1}$ point.

Under the model (1), (2e), (3e) convergence of low-production Ukrainian economy with highly productive economies in the EU leads to increased financial capacity of participants on the left maximum $U_{1}$ distribution $R(u)$. In particular, this is predetermined by the demand for their products in other countries. Consequently, the extremums of $V_{e}(u)$ potential and $R_{e}(u)$ distribution are shifting to the right: $U_{1 e}>U_{1}$. This successful management of the economy at the macro level is the result of growing financial capacity of workers and economic activity of business owners to the left maximum of $R(u)$ distribution.

Extremum $U_{2}$ meets the high-performance economic status. Principles of management of Ukrainian and European business owners with $u>U_{2}$ savings are significantly different. A unique respect for the economic participants with weaker financial capacity is dominating in western countries. This majority of the economies of the West refer to the right maximum of distribution and axis of coordinate of this maximum is shifting to the right. Participants of Ukraine's economy from the principles of behaviour $u>U_{2}$ area, especially those from the right end of the distribution $R(u)$ maintain the behaviour $d u_{2} / d t>0$ (where private savings are not reduced) $Q\left(u_{1} / p\right)<Q_{0}$ (with restriction of citizens' income) which are being implemented by economic methods (privatization, displacement of competition, monopolization of markets and pricing), and by means of government management (complication of the legal framework of economy management, restriction of licensing, financial requirement, etc.). As a result, Ukraine's economy is operating as «Maxwell demon» which is «sorting» the participants of the economy according to their financial capacity and makes it impossible to «mixing them $\gg$. This leads to shifting of the right maximum number of savings participants $U_{2}<U_{2 e}$ to the left side in the model, and reduction of the space under the graph $R_{\mathrm{e}}(u)$ on the $u>U_{e}^{\max }$ field.

The described change of management principles of business owners with high income $u>U_{2}$ is not beneficial for them in terms of short-term economic assessments. Authorities in Ukraine are not ready to abandon adopted "oligarch" principles of economy. That is why there is natural resistance to the possible convergence of Ukraine's economy with the European Union (Buyak, (2013).

Fig. 1b with shaded area shows how the economic structure of society after the beginning of convergence of Ukraine's economy with the economy of the European Union will change. Shaded area above the line $R(u)$ is describing the number of owners who have improved financial capacity by increasing the purchasing power of citizens with permanent income and as a result of changes

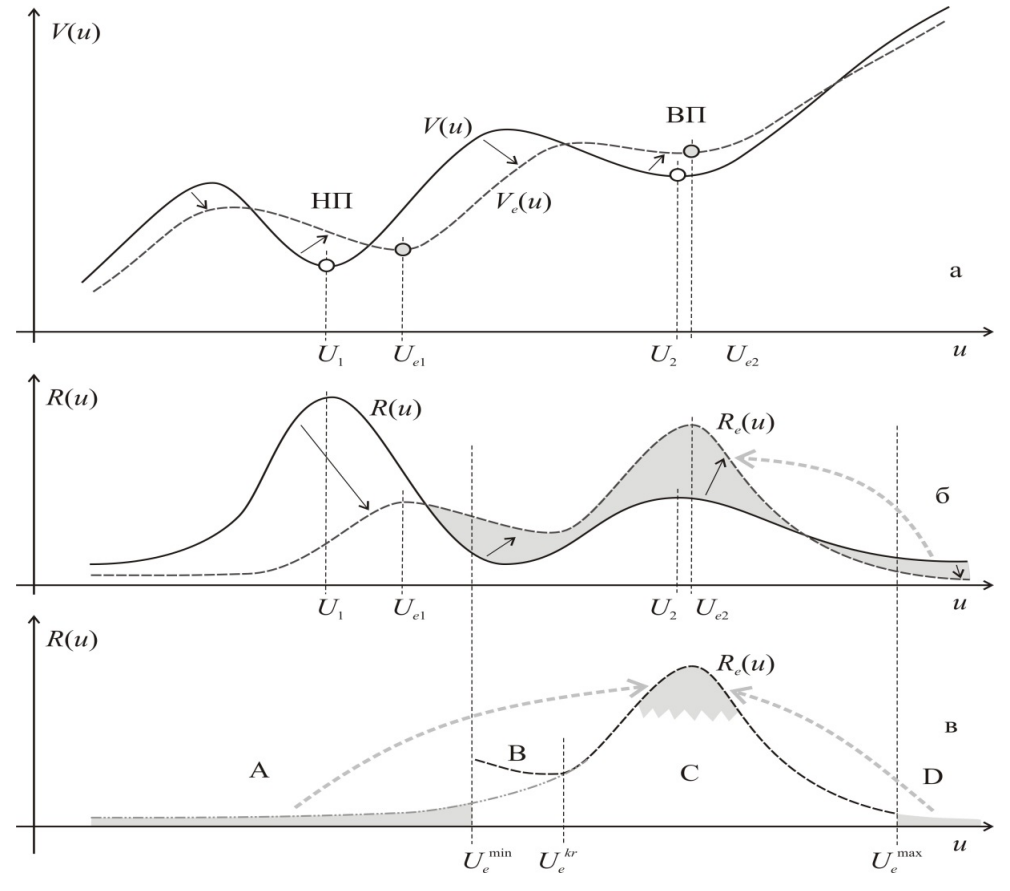

Fig. 1. Illustration of the change in the economic structure of society during the convergence of Ukrainian and the EU economies 
in the structure of expenditures of producers with a high income. The latter reduces the cost of private consumption, together with the volume of deposits and investments in other countries and therefore increase investment flow in the domestic economy. Fig. 1B has a dotted line that shows the change in the economic structure of society as a result of investing in production by business owners with high incomes. There fore it is necessary to produce raw materials with high level of processing and provide effective sales techniques etc.

Introduction of «social standards» is also associated with the convergence with the economies of the European Union. According to European standards of economic management (to prevent social tensions) it is commonly accepted to limit the number of people with a very high income $u>U_{e}^{\max }$ (see segment $\mathrm{D}$ ). To do this, a method of progressive taxation and antitrust regulation are being implemented. Restructuring of society is marked by arrows on Fig. 1B (transition from areas A and D to C) is good for society because it leads to the creation of single modal distribution of the number of people according to their income. First of all, the restructuring is favourable for business owners with average income from area $\mathrm{C}$ and skilled workers (who receive large salaries).

Social EU standards differ from the social structure of Ukrainian society. In particular, conventional boundaries of «middle class» $\left[U_{e}^{\min }, U_{e}^{\max }\right]$ does not equal to conventional boundaries of the distribution maximum $R_{e}(u)$. These differences lead to rapid transients (Buyak \& Pauchok, (2013)), which will require appropriate regulation. Distribution $R_{e}(u)$ in the area $\mathrm{B}$ is diminishing: bigger financial capacity is resulting in decreasing number of enterprises with low productivity technologies. A fragment of the distribution is indicated by a dotted line. However, according to EU standards in the field B the distribution has to increase $R_{e}(u)$ (number of workers is proportional to their skills area $\mathrm{B}$ ). The corresponding line graph is indicated by a bar-dotted line. This discrepancy is connected with the activities of companies with low financial capacity, particularly small farms. This contradiction is between national economic culture of the Ukrainian and EU standards need to be addressed without breaking the development of economic and cultural processes typical for Ukraine and preventing Russian propaganda in the matter. In particular, it is important to improve the technical equipment of individual agricultural and other farms. The economic structure of Ukraine's economy is undergoing simplification unless you take care of the elements of social structures that are illustrated by the fragment of distribution $R_{e}(u) \grave{u} \in \dot{\mathrm{u}}{ }_{e}^{\grave{u}} \quad{ }_{e}^{k r}$. So, from the above mentioned the following conclusions occur. During the convergence of the economy of Ukraine with the EU economy social and economic interests of the three participants of the economy become apparent: EU citizens, citizens of Ukraine with small and medium income (see areas A, B, C), citizens of Ukraine with high income (see area D). The introduction of European standards requires regulatory protection of small businesses with low financial capacity, especially in traditional forms of management.

\section{Mathematical model of economic convergence with Russia}

Let us consider the features of convergence of Ukraine's economy with the economy of Russia. Modern Russian authorities are linking the economy with politics and it is the foundation of power and military doctrine of Russia, after all it is a common practice of commercial activities. The impact of policies on the economy can be noticed the fact that prices, tariffs, foreign exchange rates, volume of deliveries (and other items of trade relations) are set up on the basis of two factors: market value, and the «political distance» between Russia and the commercial contractor. For example, the price of gas determines the «geographical and political $\gg$ space between Russia and the importer of gas.

Another feature of the Russian economy is a frequent significant change in the scope of supply (imports, exports) as well as voluntary options parameters of commoditybased economy (prices, tariffs, rates) influenced by «change of real or imaginary political environment». Cooperative relations between Russian and Ukrainian enterprises are being ceased by Russian side, referring to certain political motives. Instead of increasing access of Ukrainian producers to the Russian market (according to preliminary political agreements) Russia is terminating exports of Ukrainian confectionery dairy and meat products, causing major losses to producers. In addition, local market research shows that in some regions Russian non-residents support the activities of privatized enterprises, while others cease their activities. It shows that the Russian policy of «intermittent strong alteration of parameter in economic relations $\gg$ has a temporal and spatial aspects. Finally, it affects the financial position of business owners and workers.

So, regardless of the circumstances, commercial and political propaganda, Russia is trying to influence the economic conditions of enterprises of Ukraine through intermittent changes in activity in economic relations. From a mathematical point of view this means that the parameters of corresponding mathematical models are random values with significant variance.

Dynamics of savings of workers depends on the ratio of supply and demand and random function $\bar{\xi}_{1}(t)$ :

$$
\frac{d u_{1}}{d t}=s_{1}\left(1-\kappa_{1}\right)-p Q\left(\alpha_{1} u_{1} / p\right)+\bar{\xi}_{1}(t) \text {. }
$$

Variance $\bar{\xi}_{1}(t)$ is bigger than the variance $\bar{\xi}_{1}(t)$. Typical duration of the change $\bar{\xi}_{1}(t)$ is the length of one quarter.

For a possible convergence between Ukraine's economy with the economy of Russia, the dynamics of the savings of business owners also depends on the difference between income from sales and expenditures on consumption and production needs: 


$$
\begin{aligned}
& \frac{d u_{2}}{d t}=\frac{1}{n_{2}} \sum_{i=1}^{2} n_{1} p Q\left(\alpha_{i} u_{i} / p\right)+\tilde{p}(t) \tilde{Q}(t)[1-\tilde{\mu}(t)]-p Q\left(\alpha_{2} u_{2} / p\right)- \\
& -\frac{n_{1}}{n_{2}}\left(1+\chi_{2}\right) s_{1}-\left(\tilde{\lambda}_{2}(t)+\kappa_{2}\right) p F\left(\beta_{2} u_{2} / p\right)+\tilde{\xi}_{2}(t),(2 \mathrm{r})
\end{aligned}
$$

where $\tilde{p}(t)$ is a random price of imports to Russia, $\tilde{\mu}(t)$ is a random function describing the customs tariff; $\tilde{Q}(t)$ is a random volume of exports to Russia; $\tilde{\lambda}_{2}(t)$ is a random change of production expenses caused by the change of Russian certification requirements for imports from Ukraine; $\tilde{\xi}_{2}(t)$ is a random function with zero mathematical consumption that simulates deviation of expenditure and income owners.

Random functions in equation ( $2 r$ ) contain two additive components: deterministic trends that describe the impact of commercial circumstances and random function with zero mean, which reflects politically motivated plan:

$$
\begin{aligned}
& \tilde{p}(t)=\hat{p}+\tilde{\xi}_{p}(t) ; \tilde{\mu}(t)=\hat{\mu}+\tilde{\xi}_{\mu}(t) ; \\
& \tilde{Q}(t)=\hat{Q}+\tilde{\xi}_{Q}(t) ; \tilde{\lambda}_{2}(t)=\hat{\lambda}_{2}+\tilde{\xi}_{\lambda}(t) .
\end{aligned}
$$

Substituting these functions in equation (2r), and writing separately deterministic and random summands, we will get the following equation

$$
\begin{aligned}
& \frac{d u_{2}}{d t}=\frac{1}{n_{2}} \sum_{i=1}^{2} n_{1} p Q\left(\alpha_{i} u_{i} / p\right)+\hat{p} \hat{Q}[1-\widehat{\mu}]-p Q\left(\alpha_{2} u_{2} / p\right)- \\
& \left.-\frac{n_{1}}{n_{2}}\left(1+\chi_{2}\right) s_{1}-\left(\hat{\lambda}_{2}+\kappa_{2}\right) p F\left(\beta_{2} u_{2} / p\right)+\Xi_{2}(t), \quad \text { (3r }\right)
\end{aligned}
$$

where $\Xi_{2}(t)$,is the amount of random summands which are grouped during conversion of equation (2r) into (3r).

Dynamical Systems (1r), (3r) and have the potential $V_{1}\left(u_{1}\right)$ and

$$
\begin{gathered}
V_{r 2}\left(u_{1}, u_{2}\right)=\int_{0}^{u_{2}}\left[n_{1} n_{2}^{-1} p Q\left(\alpha_{1} u_{1} / p\right)+\hat{p} \hat{Q}[1-\hat{\mu}]-,\right. \\
\left.-n_{1} n_{2}^{-1}\left(1+\chi_{2}\right) s_{1}-\left(\hat{\lambda}_{2}+\kappa_{2}\right) p F\left(\beta_{2} u_{2} / p\right)\right] d u_{2},
\end{gathered}
$$

that is $\tilde{V}_{r}\left(u_{1}, u_{2}\right)=V_{1}\left(u_{1}\right)+V_{r 2}\left(u_{1}, u_{2}\right)$ or $u_{1}=u_{1}^{*}=$ const with $u_{2}=u$

$$
V_{r}(u)=\tilde{V}_{r}\left(u_{1}^{*}, u\right)
$$

Appropriate distribution of savings for business owners is the following:

$$
R_{r}(u)=\tilde{R}_{20} \exp \left(-2 V_{r}(u) / \tilde{G}^{2}\right),
$$

where $\tilde{R}_{20}$ is a coefficient of normalization, $\tilde{G}$ is a parameter depending on the function $\Xi_{2}(t)$. The schemes of functions graphics $V_{r}(u), R_{r}(u)$, those are functions (4r), (5r), shown in Fig. 2.

The function $\Xi_{2}(t)$ simulates discrete economic relations with Russia, which are politically motivated by Russian authorities. Therefore, the average position of balance $U_{r 1}, U_{r 2}$ lies to the right of the relevant provisions of balance $U_{1}, U_{2}$ . That is how a group of participants of economy (workers and business owners) appear. They are economically dependent on faltering exports to Russia. Dotted arrows in Fig. 2.b mark shifting of participants of the economy from the group of producers for the domestic market to a group of importers in Russia. The area of shaded elements in this figure indicates the number of participants of the economy that support economic policy of Russia. The second maximum $R(u)$ lies to the right of the second maximum $R(u)$. Variance $\Xi_{2}(t)$ is bigger than the variance $\xi_{2}(t)$.

This suggests that the distance between the balance position in low- and high-performance conditions described by potential (4), is bigger than that distance to the system described by potential $(4 \mathrm{r})$ :

$$
\left|\left(U_{1}, V\left(U_{1}\right)\right)\right|<\left|\left(U_{r 1}, V_{r}\left(U_{r 1}\right)\right)\right| \text {, }
$$

where the symbol $\mid . .$. indicates the standard in the space of values. This means that during the intermittent economic interaction with Russia, the possibility of accidental transfer of enterprises with high-performance into lowperformance conditions is decreasing, in particular on the basis of the phenomenon of stochastic resonance.

\section{Conclusion}

Trade with the countries which are non-members of the $\mathrm{CU}$ remains a key factor of economic development of the CU countries. Secondly, there are no definitive assessments of the positive or negative effect of integration within the Customs Union for now. The lack of significant effects of reintegration for mutual cooperation, possibly indicate the error of Russian experts concerning assumptions of high growth potential in member-countries as a result of the creation of new integration bloc. The results of modelling and integrated assessment of scenarios of interaction of Ukraine with the CU show that the most appropriate scenario for Ukraine is the following: «Ukraine out of the MS: status quo $+\gg$. In this scenario, Ukraine keeps the advantages of being open for cooperation with key partners, and has benefits from the strengthening of economic sovereignty, based on diversified development strategy and energy efficient economy.

Comparison of the economic impact of a possible convergence of Ukraine with the economies of the European Union and Russia. Comparison of the economic

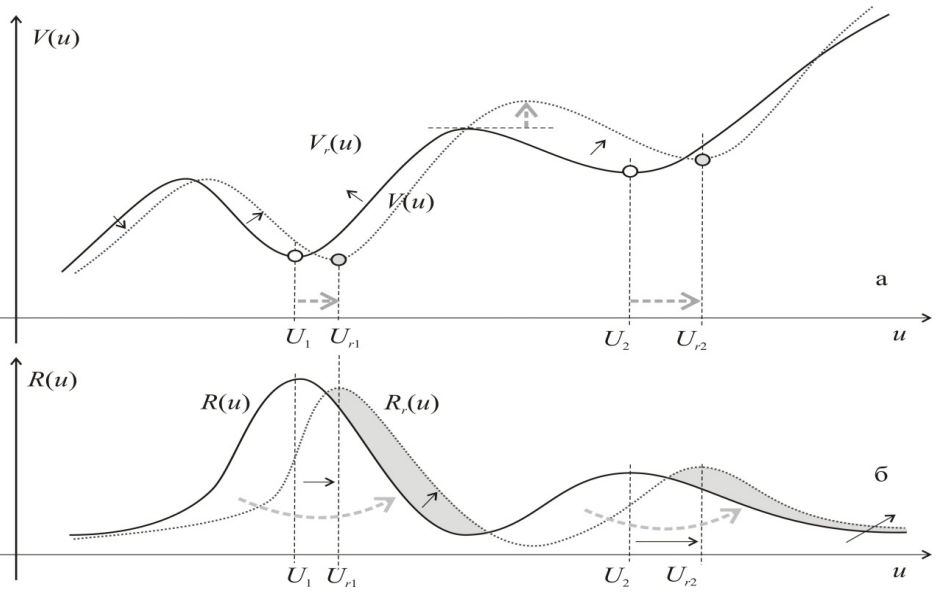

Fig. 2. Illustration of the change in the economic structure of society during the convergence of Ukrainian and Russian economies 
impact of a possible convergence of Ukraine with the economies of the European Union and Russia leads to the following conclusions. Convergence of Ukraine with Europe requires from Ukrainian enterprises the improvement in all aspects of management in order to step into the EU market, which is politically affordable. A prerequisite for this is a change in the principles of economic management. During the convergence with the EU it is necessary to introduce «social standards», use special measures to preserve traditional forms of business management, despite their temporary low financial capacity. That is, convergence with the EU economy leads to the transformation of modern closed economy in Ukraine to an open economy with a possible transition to its high-performance condition, what is called «economic miracle». The convergence of the economies of Russia closes down, for a long time, a modern type of economic relations with its inherent biting social contradictions, political and economic dominance of the owners of large enterprises, loss of economic and political rights by citizens, weakening of the sovereignty of the country.

\section{References:}

Buyak, L.M. \& Pauchok, V.K. (2012). Ukraine on the Border Between East and West: Economic and Mathematical Model and Analysis of Its Solutions. Ternopil. Grehit: 72.

Buyak, L.M. (2013). Basic Mathematical Model of Socio-Economic Processes in the European Union. Naukovyy visnyk NLTU Ukrayiny, 23(3): 362-369.

Buyak, L.M. \& Pauchok, V.K. (2013). Mathematical Model of a Possible Complex Open Economy of Ukraine. Naukovyy visnyk NLTU Ukrayiny, 23(15): 342-352.

Hnativ, B.V., Kostrobiy, P.P. \& Tokarchuk, M.V. (2011). Mathematical Modeling of Economic Processes by Nonequilibrium Statistical Mechanics. Visnyk Natsionalnoho Universytetu «L'vivs'ka politekhnika», 696: 93-100.

Malkov, S.Yu., Malinetskiy, G.G. \& Kurdyumov, S.P (2002). Mathematic Modelling of Historical Provesses. Moscow: Nauka.

Tikhonov, V.I (1982). Statistic Radio Engineering. Moscow: Radio i svyaz: 624.

Toshkov, D. (2011). Transposition of EU Social Policy in the New Countries - EU Member States. Journal isssledovaniy sotsyalnoy politiki, 8(3): 295-318.

Chernavskiy, D.S., Starkov N.I. \& Shcherbakov A.V. (2002). On Problems of Physical Economy. UFN, 9(9): 1045-1066.

\section{Леся БУЯК, Мария ГРИГОРКИВ \\ МОДЕЛИРОВАНИЕ ВОЗМОЖНЫХ ПОСЛЕДСТВИЙ ИНТЕГРАЦИИ ХОЗЯЙСТВА УКРАИНЫ В ЭКОНОМИКУ ЕВРОСОЮЗА И РОССИИ}

Аннотация. Целью работы является математическое моделирование процесса экономического партнерства двух стран и качественный анализ математической модели, который включает следующее: наметить пути возможного развития событий, сформулировать требования по выбору управляющих параметров и коэффициентов модели, предоставить экономическое толкование результатам моделирования, реальную альтернативу сценария экономической кооперации. Методика. Для исследования возможных социально-экономических последствий интеграции хозяйства Украины в экономику Евросоюза или России применены методы математического моделирования. Стационарные решения моделей отражено потенциалами соответствующих динамических систем и распределением количества участников экономики по сбережениям. Результаты. Построены базовая математическая модель экономики Украины и две математические модели возможного ее сближением с экономикой Евросоюза или России, используя теорию экономической динамики. На основе экономического анализа математических зависимостей установлено выводы о возможных экономических последствиях интеграции хозяйства Украины в экономики Евросоюза или России. Практическое значение. В частности, установлено, что сближение с Евросоюзом требует предварительной изменения принципов хозяйственного управления, своевременных мер государственного регулирования при реформировании социальных стандартов и практики коммерческой деятельности, особенно - в отношении традиционных форм хозяйствования предприятий с низкой финансовой возможностью. Сближение с экономикой России предопределяет консервацию современного типа экономики со многими недостатками коммерческого управления и регулирования, а также - приводит к ограничению экономических и политических свобод граждан, усиливает политическую нестабильность в стране. Значение/оригинальность. Полученные результаты расширяют современный экономико-математический инструментарий исследования интеграционных процессов и принятия соответствующих экономических решений. Формализация моделей экономики с учетом влияния экономически структурированного общества на экономическое развитие позволяет на модельном уровне исследовать сложные динамические процессы интегрирования хозяйства Украины в экономику Евросоюза или России. 